\title{
Auction Rate Securities ${ }^{1}$
}

Auction Rate Securities (ARS) were marketed by broker-dealers to investors, including individuals, corporations and charitable foundations as liquid, short-term, cash-equivalent investments similar to traditional commercial paper. The securities, however, were long-term floating rate bonds or preferred stock with floating rate coupons which gave them a superficial similarity to short-term investments.

ARS's liquidity and similarity to short-term investments were entirely dependent on the presence of sufficient orders to buy outstanding ARS at periodic auctions in which they were bought and sold subject to a contractual ceiling on the interest rate the issuer would have to pay. If the interest rate that would clear the market was greater than this maximum rate, the auctions "failed" and existing holders of the securities were forced to hold securities they wanted to sell and had previously thought were liquid.

If the demand for an ARS was too low to clear the market, broker dealers sponsoring the auction could place bids just below the maximum interest rate to clear the auction. The lower the public demand for an issue, the larger the quantity broker dealers had to buy to avoid a failed auction.

Participating broker dealers had better information than public investors about the creditworthiness of the ARS issuers and were the only parties with information about the broker dealers' holdings and inclination to abandon their support of the auctions. In addition, brokerage firms involved in the auctions knew of temporary maximum rate waivers negotiated with the issuers and the ratings agencies that allowed auctions that would have failed in late 2007 to continue to clear. This severe asymmetry of information made public investors in ARS vulnerable to the brokerage firms' strategic behavior.

In this paper, we explain what auction rate securities were, how they evolved, how their auctions worked, and why their flaws caused them to become illiquid securities.

\section{Introduction}

Auction Rate Securities (ARS) were long-maturity floating rate securities issued by municipalities, closed-end mutual funds, structured finance trusts and corporations. Their coupon payments were determined within limits by supply and demand in periodic Dutch

\footnotetext{
${ }^{1}$ (C) 2011 Securities Litigation and Consulting Group, Inc., 3998 Fair Ridge Drive, Suite 250, Fairfax, VA 22033. www.slcg.com. The primary authors can be contacted at craigmccann@slcg.com or 703-246-9381 and eddieoneal@slcg.com or (336) 655-8718. We received helpful comments from Guohua Li, Joshua Mallett and Joseph Prendergast.
} 
auctions held at intervals of 7, 14, 21, 28 or 35 days. ${ }^{2}$ At each auction, buyers and sellers were constrained to pay par value for the securities but could bid on the interest rate that would be paid by the issuer until the next auction. When an auction cleared, buyers paid the par value of the bonds, and received the (auction) market clearing interest rate at the next auction if there were sufficient buyers. ${ }^{3}$ As long as the ARS could be sold at the auctions, investors effectively held a short-term security.

ARS were marketed by broker-dealers as liquid investments, alternatives to money markets, and cash-equivalent investments, but the design of the securities exposed investors to significant liquidity risk. In particular, ARS did not have a "put” feature that granted investors an option to force the issuer to buy the bond back at par, as is the case with true short-term securities such as variable rate demand notes or tender option bonds. It was only the continued success of the periodic auctions that created the appearance that these longterm securities were short-term securities. ${ }^{4}$

In a successful auction, a single market clearing coupon rate was determined that equated the amount of securities participants were willing to buy to the amount of securities participants were willing to sell. If there were insufficient buyers to clear the market at any coupon rate below the "maximum rate" specified in the security's prospectus, the auction failed and the coupon was set to the maximum rate. This restriction on how high the coupon rate could be was economically equivalent to setting a floor on the price at which the bonds could be sold in the auction. In 2007 and 2008, the ARS were recognized to be worth less than this effective minimum price, the auctions failed and investors were stuck holding securities they couldn't sell. Moreover, the way the maximum rate was determined was often complex and opaque. Thus, many investors would not have been able to tell when market clearing coupon rates were getting close to the maximum rate and therefore when auctions were close to failing.

\footnotetext{
${ }^{2}$ In financial markets, Dutch auctions are also known as uniform-price or single-price auctions. In these auctions, each winning bid is filled at the lowest winning price (or highest winning yield). See Back and Zender (1993).

3 “Auction Rate Securities,” California Debt and Investment Advisory Commission, August 2004.

${ }^{4}$ Adrian D’Silva, Haley Gregg and David Marshall, “Explaining the Decline in the Auction Rate Securities Market,” Chicago Fed Letter, November 2008.
} 
Prior to 2007, auction failures were infrequent. In August 2007, the market's assessment of the risk in auction rate securities increased and some auctions failed as the interest rate that would clear the auction exceeded the maximum rates issuers and underwriters agreed would be paid. In the last half of 2007, the financial condition of monoline bond insurance companies that had guaranteed subprime mortgage backed securities deteriorated. These insurers also guaranteed municipal bonds, many of which were issued in ARS form. With the capital adequacy of the monoline insurers in doubt, investors increased their assessment of credit risk in municipal ARS. In addition, as financial conditions worsened generally, investors increased the liquidity premium they required to hold all but the safest, most liquid securities. In February 2008 the auction market failed en masse. As a result, the majority of ARS investors were unable to liquidate their holdings when they needed cash and suffered sizeable damages.

The auction failures were not the result of dramatic contemporaneous market events. The design of auction rate securities and the manipulated implementation of the auctions led to auction failures. The coupon rates determined in ARS auctions were limited to a maximum rate (or cap) defined in each security's prospectus. If the credit or liquidity risk of a particular ARS warranted a higher coupon rate than the maximum rate, the auction would fail. McConnell and Saretto (2008) found empirical evidence that auctions failed because of "maximum rates" that constrained the ARS coupons to be below what was required to compensate investors. Also, the broker-dealers that underwrote, distributed and remarketed ARS propped up auctions by bidding when the demand for particular ARS was too low to clear the auction at interest rates below the maximum rate allowed in the ARS's prospectus. ${ }^{5}$ The repeated undisclosed involvement of the broker-dealers allowed auctions to clear that would have otherwise failed and gave ARS an artificial appearance of liquidity.

In late 2007 and early 2008, broker-dealers saw their inventories of auction rate securities increase dramatically as the brokerage firms had to buy more and more of the securities to keep the auctions from failing. The issuers of some auction rate securities

\footnotetext{
${ }^{5}$ In 2006, 15 broker-dealers settled with the SEC. The SEC found that the broker-dealers intervened in auctions to prevent auctions from failing without adequately disclosing their interventions, and that investors may have been unaware of the liquidity or credit risks associated with ARS because the brokerdealers prevented auctions from failing. See "15 Broker-Dealer Firms Settle SEC Charges Involving Violative Practices in the Auction Rate Securities Market,” SEC Press Release 2006-83.
} 
temporarily waived maximum rates; without these waivers it would have been more costly for the brokerage firms to force the auctions to clear. When the brokerage firms ultimately withdrew their support for auctions there was a precipitous drop in liquidity for investors. If it were not for the brokerage firms' non-public and increasing intervention in the auctions, investors would have been able to observe the ARS gradually become riskier and illiquid. ${ }^{6}$

Absent manipulation of the auctions, interest rates paid at the auctions would have increased gradually and auctions of the poorest ARS would have failed early. Then issuers of the higher quality ARS would have gradually redeemed the securities or would have permanently adjusted the maximum rate formulas to allow the auctions to clear.

When auctions failed, some investors suffered significant damages. For example, while many auction rate securities issuers were forced to pay interest rates at or above market when auctions failed, student loan auction rate securities (“SL ARS”) issuers paid interest rates substantially less than what was required to compensate investors. Figure 1 reports the yield on AAA-rated, student loan asset backed securities (“SL ABS”).

Figure 1. SL Asset Backed Securities yields ${ }^{7}$ and indicative SL Auction Rate Securities yields.

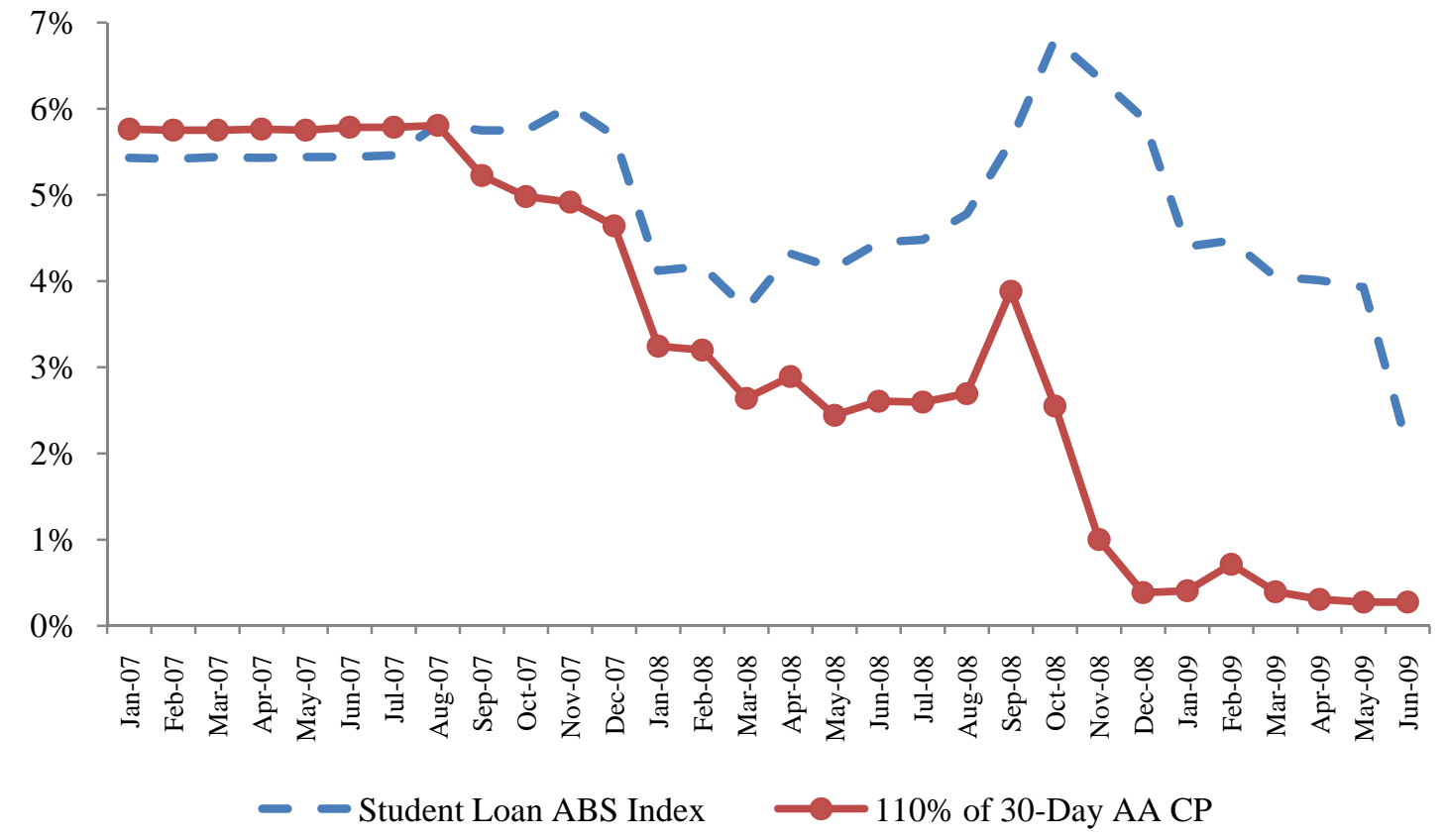

\footnotetext{
${ }^{6}$ In a Federal Reserve Board paper, Han and Li (2008) found that the withdrawal of support by brokerdealers resulted in the collapse of the ARS market and revealed the flawed design of the ARS product.

${ }^{7}$ Bloomberg Ticker: BBALYL5 Index.
} 
These SL ABS are issued by the same issuers and backed by the same student loans as the SL ARS. Until mid-2007, the maximum rates payable on SL ARS - approximated by $110 \%$ of the 30 -day AA financial commercial paper yield - were slightly higher than the yield on otherwise equivalent SL ARS. As the auctions started to fail in late 2007 the spread between what investors earned on SL ABS and what investors earned on SL ARS increased substantially. Investors stuck holding SL ARS in 2008 and 2009 were receiving yields around $1 \%$ when yields of $4 \%$ or $5 \%$ were being paid to investors in otherwise identical securities that were not subject to the auctions. It was the substantially below market interest paid to investors in the SL ARS that explains the low secondary market prices after the auctions failed.

In addition, investors missed valuable investment opportunities for lack of funding, paid penalties for reneging on existing agreements, or were forced to obtain financing at high interest rates. Investors experienced especially large losses on auction rate securities backed by risky Collateralized Debt Obligations (CDOs). Many of the CDOs that backed ARS were exposed to subprime mortgage backed securities. For these ARS, ARS investors still suffered losses even when auctions didn't fail.

The remainder of this paper proceeds as follows: First, the different types of ARS issuers are enumerated. Second, the auction process is described and illustrated. Third, a brief history of ARS markets is presented, and finally we explain why adverse incentives built into ARS and the auctions can easily explain the auction failures in 2007 and 2008.

\section{Types of Auction Rate Securities}

Auction rate securities are long-maturity floating rate securities issued in the form of bonds or preferred stock. The term "floating rate" means that the coupon rate (or dividend, in the case of preferred stock) varies over time. This is opposed to, for example, a fixed rate bond which promises a constant coupon payment over its life. What distinguished auction rate securities from other floating rate securities was how the coupon rate was determined. In most floating rate securities, coupon rates are specified as a fixed spread to or multiple of a benchmark or reference interest rate such as 1-month 
$\mathrm{LIBOR}^{8}$ or a constant-maturity Treasury rate, and the price of the bond is allowed to vary up or down to the extent the specified coupon rate over- or under-compensates for liquidity risk, credit risk and interest rate risk. In contrast, ARS prices were fixed at par and the spread to reference interest rates was allowed to vary subject to a cap to compensate for liquidity risk, credit risk and interest rate risk. The auction mechanism would have continued to clear the market except the coupon rates were not allowed to increase enough to compensate for increasing liquidity risk, credit risk and interest rate risk in 2007 and 2008.

The auction mechanism was used by a variety of issuers including municipalities, closed-end mutual funds, student loan trusts, asset-backed collateralized debt obligations (CDOs) and corporations. Table 1 reports the amount of ARS outstanding as of December 31, 2007 by type of issuer. ${ }^{9}$

Table 1

Auction Rate Securities Market Composition

(December 31, 2007)

\section{Type}

Municipal Bonds

Tax-Exempt

Taxable

Student Loans

Tax-Exempt Student Loans

Taxable Student Loans

Investment Company Preferred Stock

Tax-Exempt Preferred Stock (closed end fund)

Taxable Preferred Stock (closed end fund)

Corporate Preferred Stock

Other $^{10}$

Total
Amount Outstanding

(\$Billions)

$\$ 146$

$\$ 19$

$\$ 85$

$\$ 29$

$\$ 56$

$\$ 63$

$\$ 30$

$\$ 33$

\footnotetext{
${ }^{8}$ LIBOR (London Interbank Offered Rate) is the interest rate at which banks borrow from each other in the London interbank market. T-Bills are short-term obligations of the US Government. LIBOR rates are commonly used benchmarks for fixed income securities as are Treasury yields. LIBOR swaps and futures markets are highly liquid, but the rate typically contains a small credit risk premium. T-Bills, on the other hand, are effectively riskless, but their markets are sometimes subject to technical dislocations. Thus, both have advantages and disadvantages as riskless benchmarks.

${ }^{9}$ Cross Product Research, Bank of America, February 13, 2008.

10 This category includes, for example, non-student loan asset backed securities.
} 


\section{a) Municipal ARS}

City and local governments (or their agencies) were the largest issuers of auction rate securities. Most of the ARS issued by these municipalities were exempt from federal income taxes and from income taxes levied by the state in which the bond was issued. Many municipal ARS were guaranteed by municipal bond insurance companies such as Ambac and MBIA, meaning that the insurers would advance interest and principal payments in the event of a default by the municipal issuer. Thus, in addition to the financial condition of the municipal issuer, the financial condition of the insurers could affect the credit risk of the ARS.

As an example of a municipal ARS, in 2002, ABAG Finance Authority for Nonprofit Corporations issued $\$ 71,500,000$ of revenue bonds in the form of auction rate securities to fund the de Young Museum project in San Francisco. The auctions for these ARS were conducted at 7-day intervals. The prospectus defines the maximum rate as follows:

"ARS Maximum Rate" means, on any date of determination, the interest rate per annum equal to the lesser of (i) the Applicable Percentage of the higher of (A) the After-Tax Equivalent Rate on such date, and (B) the Index on such date, and (ii) $12 \%$ per annum; provided, that in no event shall the ARS Maximum Rate be more than the Maximum Lawful Rate.

"After-Tax Equivalent Rate" means, on any date of determination, the interest rate per annum equal to the product of (i) the "AA" Composite Commercial Paper Rate on such date and (ii) 1.00 minus the Statutory Corporate Tax Rate on such date.

"Index" means, with respect to each Series of ARS, on any date of determination, the BMA Index or, if such rate is not available, the Index so determined by the Market Agent for each Series of ARS, which shall equal the prevailing rate for bonds rated in the highest short-term rating category by Moody's and S\&P that are subject to tender by the holders thereof for purchase on not more than seven (7) days notice and the interest on which is (i) variable on a weekly basis, (ii) excludable from gross income for federal income tax purposes under the Code, and (iii) not subject to an "alternative minimum tax" or similar tax under the Code, unless all tax-exempt bonds are subject to such tax.

The ABAG Finance Authority ARS's maximum rate is determined by a complex combination of various fixed and floating rates. It would have been difficult for most 
investors, on any given date, to calculate the maximum rate. The broker dealers who were intervening to keep the auctions from failing knew how close the auctions were to failing and how much longer the firms would wait before letting the auctions fail. Even the most sophisticated investors would not have this critical information. The weekly auctions for this ARS issue began to fail on February 20, 2008 and have been failing ever since. Figure 2 shows a partial history of the ARS coupons. The coupon rate continued to vary over time after the first auction failure indicating that the floating rate elements of the calculation were determining the coupon and not the fixed rate elements.

Figure 2 Failed Auction with a Maximum Rate (Minimum Price)

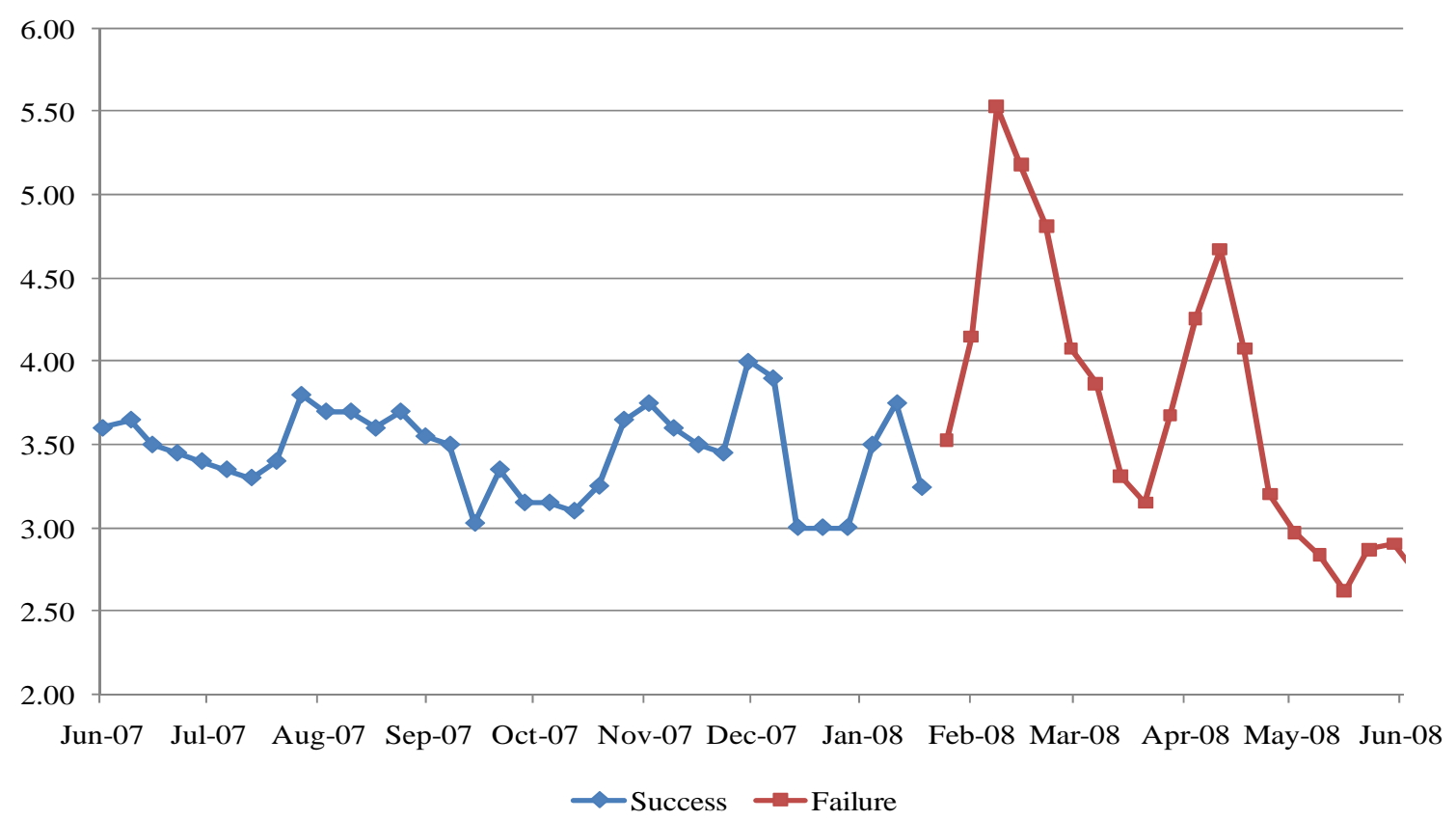

As municipal bond insurers' exposure to losses on subprime mortgage backed securities increased, the credit quality of the ARS declined. Many of these insurers were subsequently downgraded in 2008. Sophisticated investors concluded that the insurers would not have adequate capital to meet their subprime obligations given the risk of default in subprime mortgage backed securities, and as a result also might not be able to honor their ARS obligations. As a result of the increasing credit and liquidity risk in the ARS, investors demanded coupon rates higher than the maximum allowable rate, and there were not enough buyers for a successful auction without increasing broker-dealer intervention. 


\section{b) Closed-end funds Auction Rate Preferred Shares}

Closed-end mutual funds sometimes issued a form of auction rate security called an Auction Rate Preferred Share (ARPS). Closed-end funds are a type of investment company that issues shares which trade on exchanges. Unlike open-end mutual fund units which are issued or redeemed each day by the mutual fund company, closed-end funds are closed to new capital after the initial offering. Closed-end fund share prices are determined by supply and demand and typically trade at a premium or discount to the fund's Net Asset Value (NAV). Also, in contrast to open-end funds, closed-end funds commonly borrow to invest more than the amount raised in their common shares offerings. Some closed-end funds borrowed by issuing preferred stock, some of which had been issued in auction rate form. The dividends paid on these Auction Rate Preferred Shares (ARPS) were set in auctions.

As an example, the BlackRock MuniYield Insured Fund issued \$320,000,000 of Auction Rate Preferred Shares (which Blackrock called Auction Market Preferred Stock). The auctions for these ARPS were conducted at 7-day or 28-day intervals depending on the particular series. The maximum rate for these ARPSs depended on their credit rating at the time of the auction. As shown in Table 2, various credit ratings were each assigned a multiplier which was applied to the higher of the AA composite Commercial Paper Rate published by the Federal Reserve Bank of New York and a taxable equivalent rate based on the Kenny S\&P 30-day High Grade Index:

Table 2

BlackRock MuniYield Insured Fund Maximum Rate Multipliers

\begin{tabular}{|c|c|c|c|}
\hline Moody's Rating & S\&P rating & $\begin{array}{c}\text { Multiplier } \\
\text { (No Notification) }\end{array}$ & $\frac{\text { Multiplier }}{\text { (With Notification) }}$ \\
\hline Aa3 or higher & AA- or higher & 1.10 & 1.50 \\
\hline A3 to A1 & A- to A+ & 1.25 & 1.60 \\
\hline Baa3 to Baa1 & $\mathrm{BBB}-$ to $\mathrm{BBB}+$ & 1.50 & 2.50 \\
\hline Below Baa3 & Below BBB- & 2.00 & 2.75 \\
\hline
\end{tabular}

If the Fund notified the Auction Agent that net capital gains or other taxable income were to be be included in the dividend, the "With Notification" multiplier was used; otherwise the "No Notification" multiplier was used. 


\section{c) Student Loan Trusts}

Student Loan Asset Backed Securities (ABS) were issued by trusts that purchased and held student loans as collateral. The student loans were typically originated under the Family Federal Education Loan Program (FFELP). ${ }^{11}$ The majority of the principal and interest of FFELP loans was insured by the U.S. Government and credit risk was minimal. The trusts often issued two types of asset backed securities: auction rate securities and floating rate securities indexed to LIBOR.

As an example, in 2004 the Missouri Higher Education Loan Authority issued $\$ 700,000,000$ of Student Loan Revenue Bonds in the form of auction rate bonds. The issue consisted of tax exempt senior, taxable senior and taxable subordinate auction rate bonds. In particular, Series 2004F bonds were taxable senior auction rate bonds and had an auction period of 28 days. The auction mechanics for the 2004F bonds were opaque and would have been difficult for most investors to understand. A “maximum interest rate” was defined to be the lesser of $17 \%$ and a statutory rate. Buy orders above the maximum interest rate were disregarded by the auction agent. A "maximum auction rate” was calculated according to a complicated formula that used the 91-day Treasury bill rate and the credit rating of the bonds. The formula reads in part:

“Maximum Auction Rate” means, for any Auction, a per annum interest rate on the Auction Rate Bonds which, when taken together with the interest rate on the Auction Rate Bonds for the one-year period ending on the final day of the proposed Auction Period, would result in the average interest rate on the Auction Rate Bonds for such period either (i) not being in excess (on a per annum basis) of the average of the Ninety-One Day United States Treasury Bill Rate plus 1.20\% for such one-year period (if all of the ratings assigned by the Rating Agencies to the Auction Rate Bonds are “Aa3” or “AA-” or better)...

For lower credit ratings, margins of up to $1.75 \%$ over the Treasury Bill Rate are specified. Finally, the "maximum rate" was defined as the lesser of the maximum interest rate and the maximum auction rate. If the market clearing rate was greater than the maximum rate then the coupon rate for the next period was set to the maximum rate. The difference between the market clearing rate and the maximum rate was "carried over" as an

11 “A Guide to Student Loan Auction Rate Securities,” Citigroup, June 23, 2005. 
amount to be paid in the future. If there were insufficient bids to clear the market then the coupon rate for the next period was set to the maximum rate.

\section{d) Other}

Some ARS are backed by Collateralized Debt Obligations (CDOs). These Credit Linked Notes (CLNs) are exposed to the same credit risk as a reference portfolio of securities. When these securities default, the principal of the CLNs is reduced. The ARS principal, in turn, is reduced by the same proportion and even if the auctions continue to clear investors can suffer capital losses. Many CDO ARS were exposed to subprime mortgage-backed securities. ${ }^{12}$

As an example, $\$ 175,000,000$ of Camber Master Trust Series 8 Auction Rate CreditLinked Note Certificates were issued on January 19, 2007 with an expected maturity date of March 20, 2017. The Auction Rate Certificates were collateralized by $\$ 350,000,000$ notional amount of Eirles Two Limited Series 316 Floating Rate Portfolio Credit-Linked Secured Notes. The Notes, along with a basis swap agreement with Deustche Bank AG, funded interest payments due on the Auction Rate Certificates. The Notes were exposed to the risk of a credit default swap which named 125 unsecured corporate notes as reference entities. The composition of the portfolio of unsecured notes is shown in Table 3:

Table 3

Camber Master Trust Series 8 Composition of Reference Entities

Credit Default Swap Exposure by Industry

$\begin{array}{lc}\text { Industrial } & 49 \% \\ \text { Financial Services } & 16 \% \\ \text { Banks } & 10 \% \\ \text { Telecommunications } & 13 \% \\ \text { Utilities } & 6 \% \\ \text { Other } & 6 \% \\ \text { Credit Default Swap Exposure by C } \\ \text { A and above } & 57 \% \\ \text { BBB } & 40 \% \\ \text { BB } & 3 \%\end{array}$

${ }^{12}$ See "Recent Developments in Auction Rate Securities Litigation,” Carrington Coleman, 18 April 2008. 
When defaults occurred in the reference entities, the principal amount of the Credit Linked Notes was reduced and, in turn, the principal amount of the Auction Rate Certificates was reduced.

Several municipal bond insurance companies issued ARS through Contingent Preferred Stock (CPS) put facilities. These facilities sold ARS to investors and purchased high quality short-term assets whose maturities matched the frequency of the auctions (typically 28 days or less). The municipal bond insurance companies, however, had the right to sell (or "put”) their preferred stock to the facilities. Thus, investors in the ARS issued by CPS facilities had exposure to the credit risk of the municipal bond insurance companies. The CPS ARS auctions were among the first auctions to fail in significant numbers in 2007, when investors became concerned about the financial condition of municipal bond insurer due to their large exposures to subprime mortgage-backed securities. $^{13}$

\section{Auction Description}

Auctions were held at intervals of 7, 14, 21, 28 and 35 days. Based on submitted buy and sell orders, the brokerage firm responsible for administering the auction determined the coupon rate to be paid for the period from the current auction to the following auction. This broker dealer, referred to as the auction agent, followed procedures stated in the security's prospectus and also acted as a transfer agent, registrar, dividend disbursing agent and redemption agent. One or more "primary" broker-dealers entered into agreements with the auction agent for exclusive rights to participate directly in the auctions. These brokerdealers, referred to as remarketing agents, submitted buy and sell orders on behalf of themselves or their clients.

As a result of the bidding, a market clearing coupon rate was set so that 1) the total quantity that participants wanted to buy at the market clearing coupon would equal the total quantity participants wanted to sell at the market clearing coupon. The market clearing coupon was capped at a "maximum rate" by each security's prospectus and could be either a fixed rate, a floating rate or some combination of the two. For example, the maximum rate

\footnotetext{
13 “Fitch Comments on Financial Guarantors Soft Capital Facilities,” Business Wire, August 15, 2007.
} 
could be set at the minimum of a fixed rate like $14 \%$ p.a. or a multiple of a floating rate, say $200 \%$ of one-month LIBOR.

In some auctions, there were not enough buyers to purchase all the securities at interest rates below the maximum interest rate. In this event, the auctions “failed," no securities were exchanged, and the coupon rate for the following period was set to the maximum interest rate. Occasionally, no existing investors offered to sell their securities. In this event, the auction was declared to be an "all-hold" auction and the coupon for the next period was set to an "all-hold rate" which was defined in each security's prospectus and was often below typical market clearing coupon rates.

ARS always traded at par or face value in the auctions. If auctions didn't fail, the auction rate securities behaved like short-term securities. To see why, consider a hypothetical ARS issue for which the interval between auctions is 28 days and the coupon rate for the period until the next auction is 0.5\%. Suppose an investor invests $\$ 100$; after 28 days he receives a $\$ .50$ coupon, sells the security at the auction, and is returned $\$ 100$ of principal. This is exactly how a short-term investment behaves - in the absence of defaults, there is no price risk at the end of the short investment period. When auctions failed, investors were not able to sell ARS at par and the securities lost their short-term character. Thereafter, until auctions resumed, the ARS behaved like long-term floating rate securities and became almost completely illiquid. These failures were likely to occur when credit risk and liquidity risk were especially high and so the market value of ARS dropped dramatically and discontinuously when auctions failed.

Despite the complex terminology sometimes used to explain auction mechanics, the basic intuition can be illustrated with simple supply and demand graphs. Approaching each auction, a current investor could decide to hold their securities unless the interest rate to be paid for the following period was too low, in which case the investor would sell. For example, an investor holding \$100,000 of a \$500 million XYZ ARS might instruct their agent to sell all $\$ 100,000$ if the market clearing interest rate is less than $3 \%$, and otherwise hold the $\$ 100,000$ position. This instruction is equivalent to telling the agent to sell all $\$ 100,000$ and buy $\$ 100,000$ if the interest rate to be paid for the following period is greater than $3 \%$. Of course, some potential buyers at an auction would not be current holders but 
their offers to buy various quantities depending on the market clearing interest rate could be specified the same way.

The Demand curves designated “ $D$ ” in Figure 3 plot the cumulative quantity investors bid to purchase the XYZ ARS at increasing possible interest rates. The supply is fixed at \$500 million in our example. If investors in total want to hold at least the entire issue at an interest rate less than the maximum rate, the auction succeeds and the interest rate for the coming interest rate period will be IR clearing. If on the other hand, investors don't want to hold at least $\$ 500$ million of the XYZ ARS at interest rates at or below the maximum interest rate, the auction fails.

Figure 3 When the demand for an issue falls (shifts to the left) so much that the market clearing interest rate exceeds the maximum allowed rate broker dealers quietly step in and buy up the excess supply or let the auction fail.

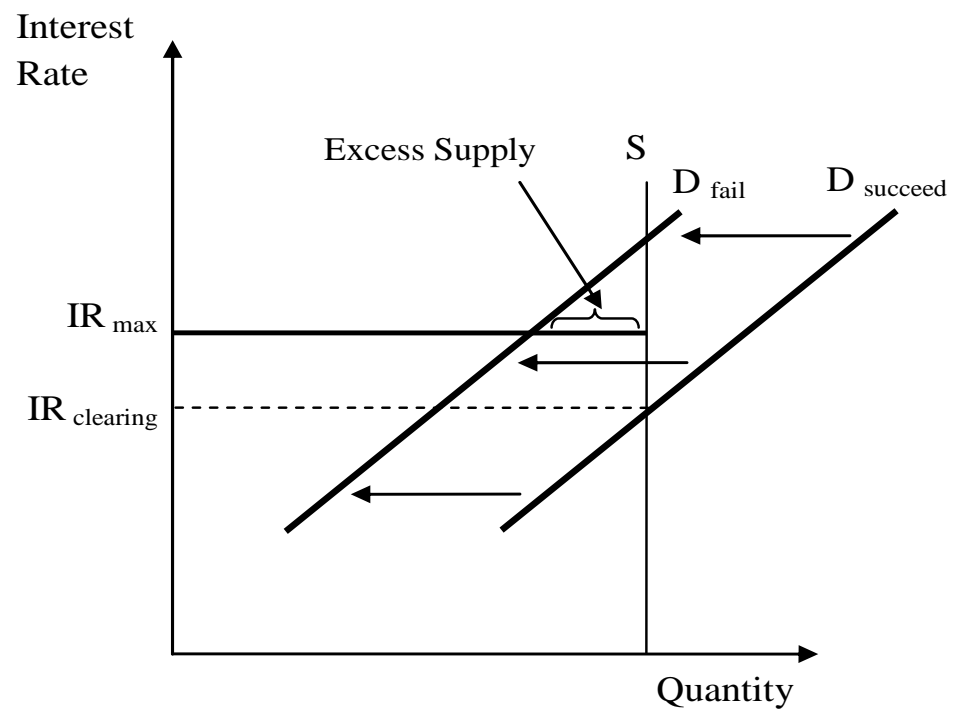

The demand and supply curves in Figure 3 are expressed in terms of quantities and interest rates. Auctions can also be described in terms of bond prices. Investors receive the principal amount plus the single coupon paid at the end of the auction period. The price of an auction rate security, like the price of a conventional zero coupon bond, is therefore the initial investment required to receive $\$ 100$ at the end of the auction period. To illustrate, if the interest rate set for the coming auction period is $1 \%$ (not annualized), then an initial investment of $\$ 1,000$ will result in a cash inflow of $\$ 1,010$ at the end of the period. Thus the initial investment that would result in a payment of $\$ 100$ at the end of the period is $(\$ 100 *$ $\$ 1,000 / \$ 1,010)=\$ 99.01$. Higher interest rates correspond to lower bond prices. 
Auctions can succeed for a time and then fail because the market's assessment of the issuer's credit risk increases or the price that the market demands as compensation for any given level of credit risk increases. Perceived increased credit risk shifts the demand curve up and to the left. It is only the imposition of the maximum rate (or minimum price) that causes the auction to fail. As shown in Figure 2, with no constraints on the coupon rate or, equivalently, the bond price, the same set of buy and sell orders results in a successful auction.

If the demand for an ARS is too low to clear the market, the broker dealers sponsoring the auction can place bids just below the maximum rate and the auction will clear. The lower the actual demand for an issue, the larger the quantity broker dealers must bid to avoid a failed auction. If the decline in actual demand is temporary the sponsoring broker dealers will find it profitable to support the auction since they receive underwriting and other fees and are being paid at or near the maximum rates on their ARS holdings. Participating broker dealers have much better information than public investors about the creditworthiness of the ARS issuers and how close auction-determined rates are to the maximum rates. The broker dealers are the only parties with information about their holdings and inclination to let the auctions fail. This severe asymmetry of information made public investors in ARS vulnerable to the brokerage firms' strategic behavior.

\section{Brief History of ARS}

The first ARS were issued in $1984^{14}$ and the early ARS issuers were predominantly corporations. In the early 2000s, municipalities became increasingly important issuers of ARS, ${ }^{15}$ most of which paid coupons that were exempt from federal and state income taxes (in the state of issue). Closed-end mutual funds, CDOs and Student Loan ABS trusts also issued significant amounts of ARS.

ARS were often marketed by broker-dealers as “cash-equivalents” which became a focus of concern in the 2004 to 2007 timeframe, especially to the Financial Accounting Standards Board (FASB) and major accounting firms. Upon examining FAS 95 in 2005, Price Waterhouse Coopers concluded that "Most auction rate securities have maturities that

\footnotetext{
${ }^{14}$ Adrian D’Silva, Haley Gregg and David Marshall, “Explaining the Decline in the Auction Rate Securities Market," Chicago Fed Letter, November 2008.

15 “Auction Rate Securities,” California Debt and Investment Advisory Commission, August 2004.
} 
span many years, and such securities will not qualify as cash equivalents.”16 In March 2007, FASB decided that "the notion of cash equivalents should not be retained in financial statement presentation." ${ }^{\prime 17}$

The trading practices of broker-dealers who sold ARS also came under close scrutiny in 2006, when 15 broker-dealers settled with the SEC over allegations that the brokerdealers did not adequately disclose to investors that they were intervening in ARS auctions during the 2003-2004 timeframe “by bidding for [the broker's] proprietary account or asking customers to make or change orders in order to prevent failed auctions, to set a 'market' rate, or to prevent all-hold auctions.” The SEC found that due to the broker-dealers' actions "investors may not have been aware of the liquidity and credit risks associated with certain securities.” As a result, the SEC concluded that the firms violated Section 17(a)(2) of the Securities Act of 1933 "which prohibits material misstatements and omissions in any offer or sale of securities.” ${ }^{18}$ In other words, the broker-dealers were supporting the ARS auctions without disclosing their activities, and by doing so may have been creating the false appearance that the securities were liquid (and therefore short-term investments). Moreover, although the SEC required each broker-dealer to disclose its "material and current auction practices and procedures,” the broker-dealers were not required to disclose the large informational advantages and conflicts of interest inherent in their participation in the auctions.

From the inception of the ARS market in 1984 through the end of 2006, auctions occasionally failed although failures were not widespread. In mid-2007, however, ARS auctions failed in larger numbers. In August 2007, there were several failed auctions of CPS ARS, and Fitch said that it would not be surprised to see more auctions fail in the near term. ${ }^{19}$ The CPS ARS had been issued by municipal bond insurance companies who also had large exposures to subprime mortgage-backed securities. By November 2007, auctions

\footnotetext{
${ }^{16}$ Price Waterhouse Coopers, Capital Markets Accounting Developments Advisory 2005-04, March 4, 2005.

${ }^{17}$ FASB Board Meeting Minutes, March 27, 2007.

18 "15 Broker-Dealer Firms Settle SEC Charges Involving Violative Practices in the Auction Rate Securities Market,” SEC Press Release 2006-83.

19 “Fitch Comments on Financial Guarantors Soft Capital Facilities,” Business Wire, August 15, 2007.
} 
for approximately $\$ 6$ billion of corporate ARS had failed (including the CPS put facility failures). ${ }^{20}$

Figure 4 illustrates graphically that signs of stress were emerging in ARS markets by as early as August 2007. The figure shows the spread between the SIFMA Auction Rate 1 Month Taxable Index ${ }^{21}$ and two benchmarks: 1) the 1 Month LIBOR Rate and the 2) 30-Day T-Bill Yield. ${ }^{22}$ Figure 4 indicates that the risk premium for ARS increased in August 2007, at approximately the same time that the CPS ARS auctions failed. Prior to that time, the spread was stable and close to zero. The SIFMA/T-Bill spread also increased sharply in August. Both spreads increased sharply again in late November 2007.

Figure 4 History of ARS Coupon Spreads

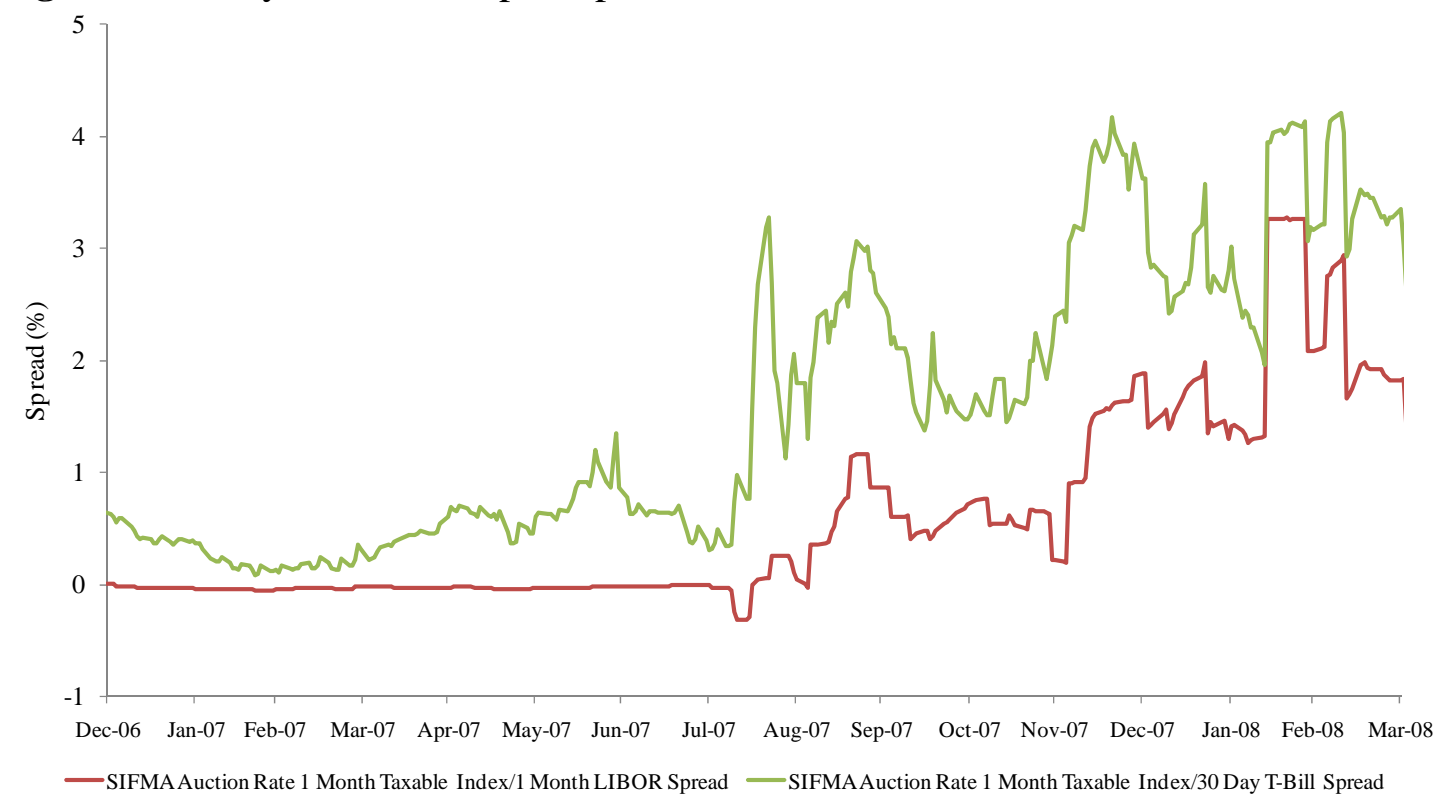

At least as early as December 2007, broker-dealers stopped supporting some ARS auctions. ${ }^{23}$ In mid-February 2008, broker-dealers stopped supporting many ARS auctions

\footnotetext{
20 “Rigged Bids, SEC Help Dealers as Auction Bonds Fail,” Bloomberg, November 21, 2007.

${ }^{21}$ The SIFMA Auction Rate 1-Month Taxable Index is an average of representative auction rates for taxable municipal ARS.

${ }^{22}$ LIBOR (London Interbank Offered Rate) is the interest rate at which banks borrow from each other in the London interbank market. T-Bills are short-term obligations of the US Government. LIBOR rates are commonly used benchmarks for fixed income securities as are Treasury yields. LIBOR swaps and futures markets are highly liquid, but the rate typically contains a small credit risk premium. T-Bills, on the other hand, are effectively riskless, but their markets are sometimes subject to technical dislocations. Thus, both have advantages and disadvantages as riskless benchmarks.

23 “Muni Update: Auction Rate Securities,” Janney Fixed Income Strategy, December 2007.
} 
and auction failures increased dramatically - on many days well over half of the auctions failed. Figure 3 shows that both SIFMA/LIBOR and SIFMA/T-Bill spreads widened suddenly and dramatically in mid-February 2008, coincident with the widespread auction failures. In response to the auction failures, secondary markets developed in which the ARS could be traded but at significant discounts to par. ARS which had previously always traded at par now sometimes could only be sold at discounts of $25 \%$ or greater. ${ }^{24}$ These discounts reflected significant illiquidity discounts from the lower prices that would have been required to clear the auctions but could not because of price floors imposed by brokerdealers.

Many firms that were involved in the sale of ARS to investors have reached settlements with federal and state regulators. As part of the settlements, the firms agreed to redeem large amounts of ARS that they sold and some have paid substantial fines. For example, the SEC reached an agreement with Citigroup in August 2008 to redeem at par $\$ 7.5$ billion of ARS that Citigroup sold to smaller investors and to make some investors whole who sold their securities at a loss in secondary markets. ${ }^{25}$ The Financial Industry Regulatory Authority (FINRA) reached an agreement with several firms, ${ }^{26}$ requiring the firms to repurchase $\$ 1.8$ billion of ARS from individual investors (at par) and to pay $\$ 3.25$ million in fines. ${ }^{27}$

State regulators have also been active in negotiating settlements with broker-dealers. Since the ARS market collapsed in 2008, state securities regulators have reached settlements with over a dozen firms to redeem more than $\$ 61$ billion in ARS. These firms include Merrill Lynch, UBS, TD Ameritrade, Bank of America, Goldman Sachs, Deutsche Bank, JP Morgan Chase, Citigroup and Credit Suisse. ${ }^{28}$ In October 2009, the State of Colorado filed charges against Stifel, Nicolaus and Co., alleging that the firm 1) had not provided training to its retail sales force regarding the risks associated with purchasing ARS or the nature of ARS investments, the mechanics of Dutch auctions and the possibility of auction failures, 2)

\footnotetext{
24 “The Nascent Secondary Market in Auction-Rate Securities,” Market Movers, April 25, 2008

${ }^{25}$ SEC Press Release 2008-168.

${ }^{26}$ The firms were SunTrust Investment Services, SunTrust Robinson Humphrey, Comerica Securities, First Southwest Company and Washington Mutual

${ }^{27}$ FINRA News Release, September 18, 2008.

${ }^{28}$ See "Wells Fargo to Repay Clients Who Held Auction Rate Securities, Dow Jones Newswires, 18 November 2009.
} 
failed to disclose the true nature of ARS investments to its clients, 3) did not disclose to its sales representatives the fact that broker-dealers had been propping up the ARS market and 4) systematically sold ARS securities to its retail customers as conservative, safe, liquid investments that were just like money market funds. In December 2009, Stifel reached a settlement with state regulators led by regulators from Colorado, Indiana, Maryland and Missouri to redeem more than $\$ 100$ million in auction rate securities from its customers. ${ }^{29}$

Many of the firms that reached settlement agreements were primary (or "upstream") broker-dealers that issued, underwrote and remarketed the securities. Others, however, were "downstream" brokers who purchased ARS from primary broker-dealers and then marketed and sold the ARS to their clients. For example, TDS Ameritrade, a downstream broker, reached a settlement with the SEC in July of 2009. ${ }^{30}$ Comerica, Fidelity, First Southwest, SunTrust and Washington Mutual are other examples of downstream brokers that have reached settlement agreements over their sales of ARS. ${ }^{31}$ Finally, in July 2009, the State of New York filed fraud charges against Charles Schwab, a downstream broker, in connection with the marketing and sale of auction rate securities.

\section{ARS Auctions Failed Because of Built-In Bad Incentives}

The way in which auctions were structured and implemented was subject to serious flaws which, when exposed to increasing credit spreads in 2007 and 2008, resulted in widespread auction failures and extreme illiquidity of investors' ARS holdings.

\section{a) Participation of Broker-Dealers in Auctions}

The SEC alleged that broker-dealers supported auctions without proper disclosure and, as a result, may have masked the liquidity and credit risk associated with auction rate securities. Recent research has shown, however, that the implicit support of dealers for auctions also contributed directly to the collapse of auction markets in February 2008. Han and $\mathrm{Li}$ (2008) used data on auction results and intraday transactions to study the role of investors and broker-dealers in the municipal auction rate security market in February 2008.

\footnotetext{
${ }^{29}$ See "State Securities Regulators Announce Settlement with Stifel, Nicolaus \& Co., Inc. in Auction Rate Securities Investigations,” NASAA News Release, December 29, 2009.

30 See “TDS Ameritrade’s Settlement Excludes RIAs,” InvestmentNews, July 26, 2009.

${ }^{31}$ See "The Collapse of the Auction-Rate Securities Market and Its Impact on the Securities Litigation Docket,” Securities Litigation and Regulation: Andrews Litigation Reporter, October 21, 2008.
} 
They found that "the decision of an unexpected first-mover to withdraw auction support, led to simultaneous withdrawal of liquidity support by other dealers” and that the withdrawal of support by broker-dealers and investor panic "amplified each other and resulted in the collapse of the ARS market.” They authors concluded that “As auctions dealers cracked under the pressure and let auctions fail, investors’ panic was further intensified. This reveals the flawed design of the ARS product, in which dealers' support is implicit, rather than explicit.”

\section{b) Maximum Rates}

ARS prospectuses specified a "maximum rate” which effectively put a floor on the price at which ARS could be traded. The maximum rate became binding when ARS investors assessed increased credit and liquidity risk in the ARS. Some issuers and ratings agencies negotiated temporary waivers of these maximum rate provisions which allowed some auctions to clear that would otherwise fail and lowered the cost to brokerage firms continuing to support the auctions.

The impact of maximum rates on auction failures is well documented in academic literature. McConnell and Saretto (2009) performed an empirical study and found that "the likelihood of auction failure was directly related to the level of the bonds 'maximum auction rates' that cap the bond yields.” The authors concluded that auctions failed because investors declined to bid for bonds when their required yield was greater than the maximum rate. McConnell and Saretto also used an empirical model to predict the hypothetical market clearing coupon rate in the absence of any rate caps. For failed auctions, these "implied" clearing coupon rates were significantly above the maximum rates. Han and Li (2008) also found that the likelihood of auction failure depended significantly on the level of the maximum rate. Thus, maximum rates caused auctions to fail that, had rates been allowed to adjust and the auctions clear, would have resulted in prices that reflected the preferences and information of all market participants.

\section{Conclusion}

Auction rate securities were long-term floating rate securities that had the superficial appearance of liquid, short-term securities when investors were able to sell their ARS at par in the frequent auctions. The success of ARS auctions was illusory and investors were 
exposed to strategic behavior by broker dealers who had tremendous informational advantages. The nonpublic participation in the auctions by broker-dealers and then their precipitous withdrawal of that support led to catastrophic spirals. In addition, the maximum allowed coupon rates meant that auctions would fail when investors would not be compensated for the credit and liquidity risk in the securities they were left holding.

\section{Bibliography}

Alderson, Michael J., Keith C. Brown and Scott L. Lummer, "Dutch Auction Rate Preferred Stock," Financial Management, Summer 1987, 16(2).

Alderson, Michael J., and Donald R. Fraser, "Financial Innovations and Excesses Revisited: The Case of Auction Rate Preferred Stock," Financial Management, Summer 1993, 22(2).

Back, Kerry and Jamie F. Zender, "Auctions of Divisible Goods: On the Rationale for the Treasury Experiment,” The Review of Financial Studies, Winter 1993, 6(4).

Bank of America, Cross Product Research, February 13, 2008.

California Debt and Investment Advisory Commission “Auction Rate Securities,” August 2004.

Carrington Coleman, "Recent Developments in Auction Rate Securities Litigation,” 18 April 2008.

Citigroup, “A Guide to Student Loan Auction Rate Securities,” June 23, 2005.

DeMarzo, Peter M., Ilan Kremer and Andrzej Skrzypacz, "Bidding with Securities: Auctions and Security Design,” Stanford Graduate School of Business, April 2004.

D’Silva, Adrian, Haley Gregg and David Marshall, "Explaining the Decline in the Auction Rate Securities Market,” Chicago Fed Letter, November 2008.

"Fitch Comments on Financial Guarantors Soft Capital Facilities," Business Wire, August 15, 2007.

"Fitch: Auction-Rate Market Disruptions May Place Stress on U.S. Student Loan ABS," Business Wire, December 19, 2009.

Han, Song and Dan Li, "Liquidity Crisis, Runs, and Security Design: Lessons from the Collapse of the Auction Rate Securities Market," Federal Reserve Board, February 15, 2008.

McConnell, John J. and Alessio Saretto, "Auction Failures and the Market for Auction Rate Securities,” Purdue University Working Paper, April 2009.

Milgrom, Paul, "Auctions and Bidding: A Primer," The Journal of Economic Perspectives, Summer 1989, 3(3). 